\title{
Influence of Climate on Carbon Sequestration in Conifers Growing under Contrasting Hydro-Climatic Conditions
}

\author{
Andrea Cecilia Acosta-Hernández ${ }^{1}$ D, Jaime Roberto Padilla-Martínez ${ }^{2}$, \\ José Ciro Hernández-Díaz ${ }^{3}$ (D) José Angel Prieto-Ruiz ${ }^{4}$, José Rodolfo Goche-Telles ${ }^{4}$, \\ Juan Abel Nájera-Luna ${ }^{5}$ and Marín Pompa-García $4, * \mathbb{D}$ \\ 1 Programa Institucional de Doctorado en Ciencias Agropecuarias y Forestales, \\ Universidad Juárez del Estado de Durango, C.P. 34120 Durango, Mexico; andrea.acostah@hotmail.com \\ 2 Forest Economics and Sustainable Land-use Planning, Georg-August-Universität, Büsgenweg 1, \\ 37077 Göttingen, Germany; jaropa24@gmail.com \\ 3 Instituto de Silvicultura e Industria de la Madera, Universidad Juárez del Estado de Durango, \\ C.P. 34160 Durango, Mexico; jciroh@ujed.mx \\ 4 Facultad de Ciencias Forestales de la Universidad Juárez del Estado de Durango, \\ C.P. 34120 Durango, Mexico; jprieto@ujed.mx (J.A.P.-R.); jgoche@ujed.mx (J.R.G.-T.) \\ 5 Instituto Tecnológico de El Salto, C.P. 34942, El Salto, Mexico; jalnajera@itelsalto.edu.mx \\ * Correspondence: mpgarcia@ujed.mx; Tel.: +52-618-1301096
}

Received: 4 September 2020; Accepted: 20 October 2020; Published: 26 October 2020

\begin{abstract}
Research Highlights: Analyzing the contrasting ecological gradients makes it easier to understand the influence of climate on carbon accumulation. Background and Objectives: The increasing climatic variability has implications for vegetation, impacting on its ecological functions, among which carbon accumulation stands out. In the present study, we used climate-dendrochronology relationships to evaluate carbon accumulation in two conifer species that grow in contrasting humidity sites: Pinus strobiformis Engelm (mesic sites) and Pinus leiophylla var. chihuahuana (Engelm.) Shaw (arid sites). Materials and Methods: Using a dendrochronological approach, we estimated the correlation of biomass and carbon accumulation of each species with some climatic variables (temperature, precipitation, and a drought index) and generated a linear mixed model. Results: The response in carbon accumulation between species with respect to climate was significantly different. P. strobiformis showed a positive correlation with the climatic variables analyzed, while in P. leiophylla the correlation was negative, except with precipitation. Conclusions: These results show that forests in both mesic and arid sites are prone to climate changes, although their responses are different, impacting the productivity and carbon cycles of forest ecosystems.
\end{abstract}

Keywords: carbon accumulation; conifers; wood density; mixed models; tree rings; dendroecology

\section{Introduction}

Climate variability is a relevant issue and significant resources have been allocated to mitigate its effects on forest ecosystems [1]. Among the impacts caused by climate changes are the decrease in the range of distribution of some forest species [2,3], even if some have developed mechanisms of adaptation to such events [4]. Forests occupy almost one-third of the earth's surface and provide direct and indirect ecosystem services [5-7]. These ecosystems are important sinks of carbon dioxide $\left(\mathrm{CO}_{2}\right)[8,9]$ and store about $45 \%$ of the terrestrial carbon [10], which is relevant given the growing emissions of $\mathrm{CO}_{2}$ from anthropogenic activities [11,12]. 
In northern Mexico, the Sierra Madre Occidental is one of the most important forest reserves of the Country, as it contributes $66 \%$ of commercial standing timber at the national level [13]. It has also great ecological importance given its contribution to carbon sequestration [14] and also, the diversity of conifers thriving there ( $46 \%$ of pine species, nationwide) [15] give ideal opportunities to understand ecological processes related to hydroclimatic variations to be experienced by these ecosystems.

By estimating rates of carbon accumulation it is possible to identify management or conservation alternatives that contribute to mitigate the concentration of atmospheric $\mathrm{CO}_{2}$, as studied by Douterlungne et al. [16], Gómez-Díaz et al. [17], Návar [18], Pompa-García [19]; however, given the great diversity of species, there are still many that have not been studied [20,21]. In this sense, it is important to develop research to evaluate the influence that the specific characteristics of the sites have on the productivity, composition and structure of forests [22].

Analyzing contrasting ecological gradients makes it easier to understand the behavior of carbon accumulation [19]. Traditional methods for estimating carbon accumulation in forests frequently use destructive procedures, having a negative impact on the forest ecosystem. Conversely, a practical methodology could be applied to calculate carbon content by estimating biomass, without compromising the reliability of the results [18]. Allometric equations using the diameter at breast height and the average density, can be used to get an accurate estimation of carbon content in an individual tree.

It is known that radial growth and wood density differ among species and sites; however, integrating these variables into allometric equations and dendrochronological studies can provide precise results $[23,24]$. Furthermore, it is possible to increase the certainty of temporal and spatial analyses when inter- and intra-specific values of carbon concentration are used [25,26]. Pompa-García et al. [19], used a dendroecological approach to prove that climate and the characteristics of the site differently affect carbon accumulation in two coniferous species representatives of Mexico [19,27].

By combining tree-ring chronologies with allometric equations, we examined whether variations in the carbon accumulation patterns of Pinus strobiformis and Pinus leiophylla var. chihuahuana respond differentially to specific hydroclimatic drivers. We assumed that our approach provides a suitable basis for testing where there are statistically significant differences in carbon accumulation rates between the two species, according to specific climatic site conditions. Our approach found species-specific responses to climatic drives. Thus, tree ring data contribute to the evaluation of dynamic carbon balance models.

\section{Materials and Methods}

\subsection{Study Area}

The study area is located within the largest mountain massif in Mexico, which is the Sierra Madre Occidental (SMO) that spreads from the southeastern United States to northern Jalisco, Mexico and contains the highest floristic diversity in this Country [28] (Figure 1). This area is an important biological corridor of great economic and environmental value due to the ecosystem services it provides [15,29]. Its great extension and heterogeneous topography, with different climatic and edaphic conditions, explain that most of the plant communities in the SMO are of the zonal type, determined mainly by climate factors [15].

Two sites with contrasting climatic conditions, located in the state of Durango, Mexico, were chosen for this study. The first is Santa Bárbara, located in the ejido El Brillante, municipality of Pueblo Nuevo, is a humid site with average annual temperature and precipitation of $11.5^{\circ} \mathrm{C}$ and $1100 \mathrm{~mm}$, being one of the areas with the highest precipitation in the State [30]. The second is a dry site located in Otinapa, municipality of Durango. It has an average annual temperature and rainfall of $12.6^{\circ} \mathrm{C}$ and $600 \mathrm{~mm}$. The climatic stations closest to the sampling sites are located at the towns of El Salto (with data for the period 1946-2016) and Otinapa (period 1962-2016). 
(a)
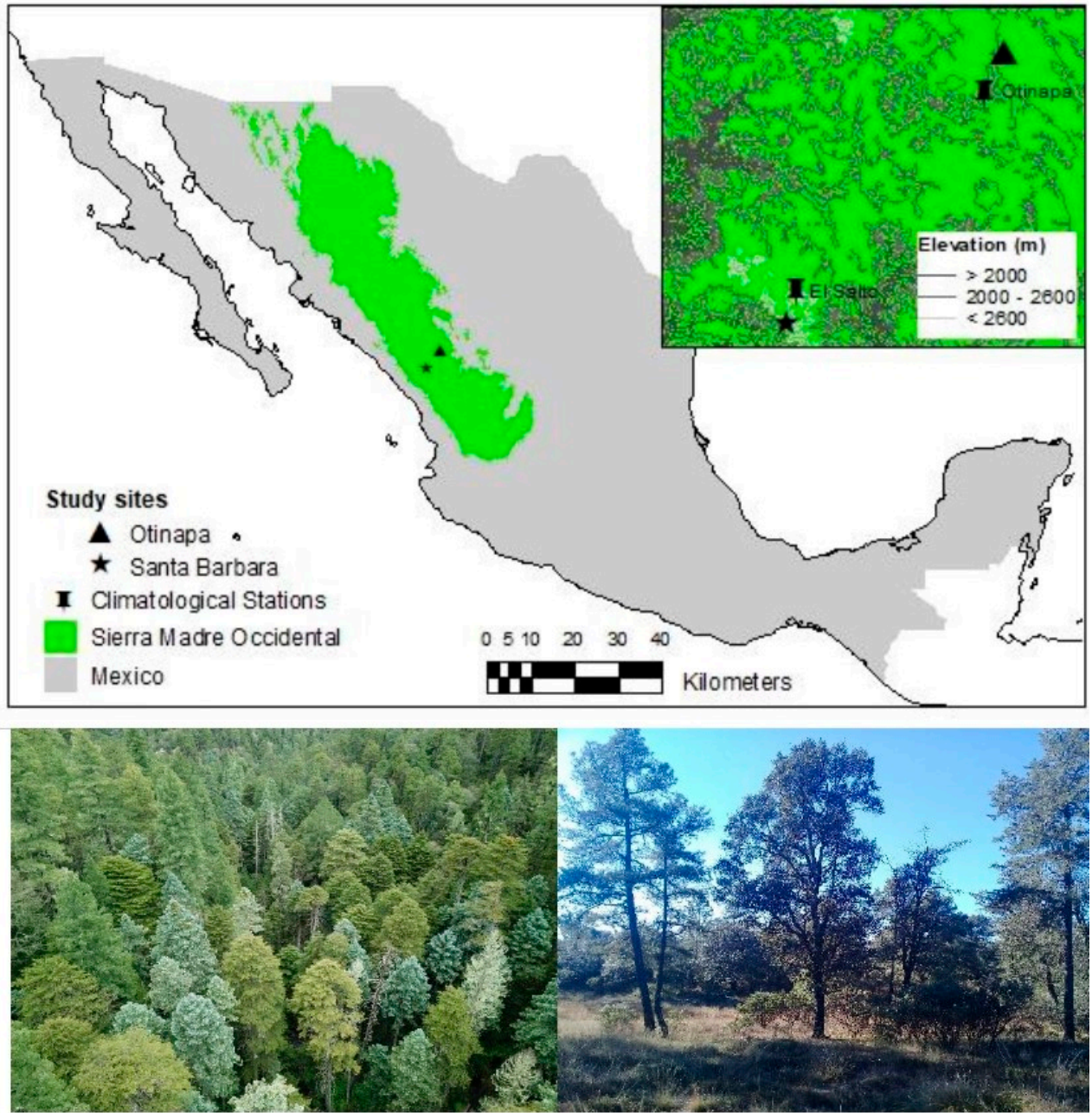

(b)

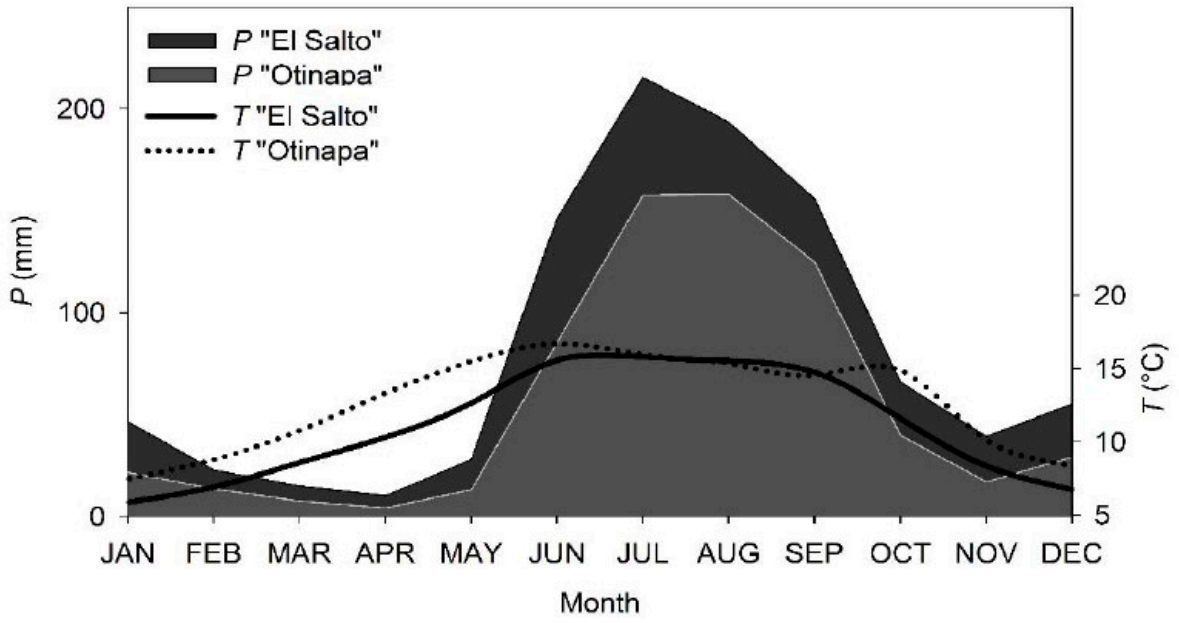

Figure 1. Location of the study sites in northern Mexico, in the state of Durango, with photographs of the ecosystems studied (a) and local climatograms of the weather stations "El Salto" and "Otinapa" (b); the diagrams show the monthly distribution of precipitation $(\mathrm{P})$ and temperature $(\mathrm{T})$. 


\subsection{Species Studied and Field Sampling}

Two species with dendrochronological potential were studied [25,31,32]. At the Santa Bárbara site, we studied Pinus strobiformis Engelm., which has been considered synonymous with Pinus ayacahuite var. brachyptera (Engelm.) Shaw, by different authors [33,34] and grows in humid streams and well-drained soils [15]. At the Otinapa site, the studied species was Pinus leiophylla var. chihuahuana (Engelm.) Shaw (hereinafter, Pinus leiophylla), which grows well in shallow and poor soils with little precipitation $[15,35]$.

The sample was taken from 15 dominant individuals selected at each site, whose general characteristics can be seen in Table 1, extracting two wood cores per individual, at $1.3 \mathrm{~m}$ in height, by a non-destructive method using a Pressler borer $(\varnothing=5.1 \mathrm{~mm}$ ) (Haglof, Sweden). This sample size has been considered to be within the adequate range to detect climatic responses and growth trends in dendrochronological studies [27]. Besides, this sampling strategy helps reducing uncertainty in quantification of the studied variables and increases the comparability between sites [36] (Table 1).

Table 1. Average characteristics of the trees studied in the dendroclimatic analysis. The expressed population signal (EPS) was > 0.85 for the analyzed period (1962-2016).

\begin{tabular}{ccc}
\hline Species & Pinus strobiformis & Pinus leiophylla \\
\hline Site & Santa Bárbara & Otinapa \\
Coordinates & $23^{\circ} 41^{\prime} \mathrm{N} 105^{\circ} 25^{\prime} \mathrm{W}$ & $23^{\circ} 58^{\prime} \mathrm{N} 104^{\circ} 57^{\prime} \mathrm{W}$ \\
Elevation $(\mathrm{m})$ & 2844 & 2430 \\
Diameter at breast height $(\mathrm{cm})$ & $38.13 \pm 1.59$ & $34.93 \pm 1.56$ \\
Height $(\mathrm{m})$ & $13.67 \pm 0.58$ & $11.33 \pm 0.75$ \\
Amplitude of the chronology & $1945-2016$ & $1934-2016$ \\
Age (years) & $49 \pm 3.11$ & $52 \pm 1.85$ \\
Ring width (mm) & $3.23 \pm 0.20$ & $\mathbf{2 . 4 9} \pm 0.11$ \\
Accumulated carbon $\left(\mathrm{g} \mathrm{cm}^{-2}\right)$ & $4.65 \pm 0.13$ & $3.05 \pm 0.07$
\end{tabular}

The means outlined in bold were significantly different $(p<0.05)$ using the nonparametric Mann-Whitney $\mathrm{U}$ test. Values are annual means \pm standard error (SE).

\subsection{Total Ring Width}

The samples (growth cores) were dried at room temperature for three days and then mounted on wooden guides. The cores were then polished with coarse to fine-grit sandpaper (80 to 1000) to highlight their growth rings. Using the standard procedure of dendrochronological techniques, the rings were counted and dated annually [37]. Total ring width (TRW) was measured with a resolution of $0.01 \mathrm{~mm}$. The dating was checked using the COFECHA program, which compares the series of each tree with a master chronology by species [38].

\subsection{Estimation of Biomass and Carbon Accumulation}

Assuming the circularity in the growth rings, the TRW values were used to reconstruct the historical diameters of the trees. To estimate biomass and carbon accumulation, the allometric equations implemented by Návar [18] were applied:

$$
\mathrm{Bt}=0.0752 \times \mathrm{D}^{2.4448} \times 2.0331^{p},
$$

where $\mathrm{Bt}=$ total aerial biomass; $\mathrm{D}=$ diameter at breast height $(1.30 \mathrm{~m})$; and $p=$ basic density $\left(\mathrm{g} \mathrm{cm}^{-3}\right)$. The basic density used for P. leiophylla was 0.44 while for P. strobiformis 0.42 [18].

The increase in diameter was calculated by multiplying by two the respective annual radial growth [39]. The annual biomass accumulation rates were calculated from the difference of the total $\mathrm{Bt}$ values between two consecutive years, these values were calculated for the common period (for both species) of the dendroclimatic analysis (1962-2016). The biomass yearly estimates were transformed into annual carbon accumulation (C). Radial growth in both studied species responded differently to 
environmental conditions, therefore, there must also have been a difference in carbon accumulation [27]. We used allometric equations to study the growth of the tree rings.

\subsection{Statistical Analysis}

Statistical differences in C and TRW between species were evaluated using the nonparametric Mann-Whitney U test paired with a 95\% confidence level. This test was applied because the values of the analyzed variables did not meet the basic assumptions of a normal distribution.

To identify the influence of the age and climatic variables on carbon accumulation, a linear mixed model was used, performing the analysis independently for each species. The tree was considered as a random effect, and as fixed effects the cambium age and the climatic variables. The model was developed using the nlme library [40] of the R statistical package [41], applying the Restricted Maximum Likelihood Method. Graphic techniques were used to verify the normality and homoscedasticity of the residuals.

To generate the chronology of the species, a standardization was carried out to eliminate biological and geometric growth trends, making them comparable with each other. We used a negative exponential model, attempting to fit a non-linear classical model of biological growth as a function of time, obtaining the ring width index. The temporal autocorrelation associated to the previous year's growth was eliminated, obtaining the residual chronologies of the sites. Standardization and timelines were developed with the $d p l R$ library in R [42-44]. To estimate the accumulation of carbon, we worked with the annual averages.

The carbon accumulation averages were significantly correlated $(p<0.05)$ with the climatic values during the common period (1962-2016). The monthly climatic variables analyzed were precipitation (P) and temperatures: maximum (Tmax), average (Tmed), and minimum (Tmin) referred to the current year and to the year prior to the formation of the ring. These data were gotten from the meteorological stations closest to each study site (Figure 1).

Finally, the relationship between carbon accumulation and drought was calculated using the Standardized Precipitation and Evapotranspiration Index (SPEI) [45], since this index considers the effect of temperature on evapotranspiration rates and quantifies the intensity of the drought on different time scales. It was calculated locally from instrumental climatological data using the R's SPEI library [46] on time scales from 1 to 24 months, and the correlations between these values and carbon accumulation were calculated.

\section{Results}

\subsection{Growth Characteristics and Carbon Accumulation}

Significant differences were found in the variables TRW and C. The species $P$. strobiformis presented significantly higher values (TRW $p<0.01$, C $p<0.05$ ). The observed average values of carbon accumulation based on the radial growth were around $4.7 \mathrm{~g} \mathrm{~cm}^{-3}$ per year for P. strobiformis and $3.1 \mathrm{~g} \mathrm{~cm}^{-3}$ per year for $P$. leiophylla, although they varied from 0.5 to $10 \mathrm{~g} \mathrm{~cm}^{-3}$ per year in the analyzed period (1962-2016). Carbon accumulation, for both species, was similar until 1995; from that year on, the increase was irregular for both species, with decreasing tendencies in P. leiophylla (Table 1, Figure 2). 


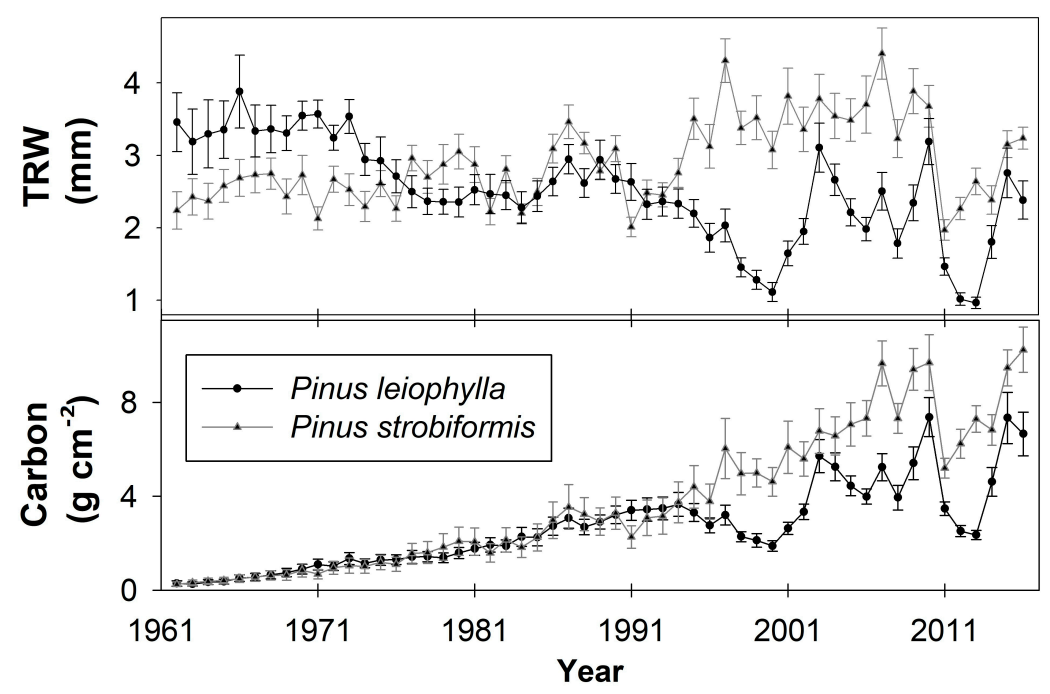

Figure 2. Average trends and standard error (mean $\pm \mathrm{SE}$ ) of the variables annual ring width (TRW) and annual carbon accumulation for the period 1962-2016.

\subsection{Internal and External Influences on Carbon Accumulation}

The variations of the random effects of the trees in the mixed model were significant $(p<0.05)$ only for P. leiophylla, which indicates that the annual accumulation of carbon differs between trees of the same species, although the explanatory variables are constant since all the sampled trees are in the dominant category and with a similar age. The opposite case was found in the behavior of $P$. strobiformis (Table 2), where only the internal influences of the ring width (TRW) and age had significant effects on the annual carbon accumulation $(p<0.0001)$.

Table 2. Estimates of mixed linear models for carbon accumulation in the tree rings of the two species studied.

\begin{tabular}{|c|c|c|c|c|}
\hline & \multicolumn{2}{|c|}{ Pinus strobiformis } & \multicolumn{2}{|c|}{ Pinus leiophylla } \\
\hline & Estimator & SE & Estimator & SE \\
\hline \multicolumn{5}{|c|}{ Fixed parameters } \\
\hline Intercept & $-3.83 \times 10^{-3}$ & $3.22 \times 10^{-1}$ & $-6.16 \times 10^{-1 d}$ & $2.64 \times 10^{-1}$ \\
\hline TRW & $2.725^{\mathrm{a}}$ & $8.00 \times 10^{-2}$ & $2.46^{\mathrm{a}}$ & $9.07 \times 10^{-2}$ \\
\hline Age & $3.67 \times 10^{-2} \mathrm{a}$ & $7.11 \times 10^{-4}$ & $2.94 \times 10^{-2} \mathrm{a}$ & $1.10 \times 10^{-3}$ \\
\hline $\mathrm{Pp}$ & $-2.65 \times 10^{-5}$ & $3.94 \times 10^{-5}$ & $1.59 \times 10^{-4 d}$ & $6.25 \times 10^{-5}$ \\
\hline Tmax & $-2.08 \times 10^{-3}$ & $1.30 \times 10^{-2}$ & $1.08 \times 10^{-2}$ & $9.46 \times 10^{-3}$ \\
\hline Tmed & $-1.58 \times 10^{-4}$ & $2.02 \times 10^{-2}$ & $-2.07 \times 10^{-2 c}$ & $6.87 \times 10^{-3}$ \\
\hline Tmin & $1.32 \times 10^{-3}$ & $1.34 \times 10^{-2}$ & $-1.83 \times 10^{-2 \mathrm{~d}}$ & $8.57 \times 10^{-3}$ \\
\hline PpPY & $-2.3 \times 10^{-6}$ & $3.97 \times 10^{-5}$ & $2.62 \times 10^{-4 a}$ & $5.88 \times 10^{-5}$ \\
\hline TmaxPY & $-1.81 \times 10^{-3}$ & $1.31 \times 10^{-2}$ & $6.35 \times 10^{-3}$ & $1.04 \times 10^{-2}$ \\
\hline TmedPY & $-3.50 \times 10^{-2}$ & $1.93 \times 10^{-2}$ & $1.15 \times 10^{-2}$ & $6.81 \times 10^{-3}$ \\
\hline TminPY & $-8.34 \times 10^{-3}$ & $1.34 \times 10^{-2}$ & $1.87 \times 10^{-2 \mathrm{~d}}$ & $8.55 \times 10^{-3}$ \\
\hline \multicolumn{5}{|c|}{ Covariance parameters } \\
\hline AIC & \multicolumn{2}{|c|}{106.1082} & \multicolumn{2}{|c|}{576.2677} \\
\hline $\mathrm{BIC}$ & \multicolumn{2}{|c|}{168.1582} & \multicolumn{2}{|c|}{638.7421} \\
\hline
\end{tabular}

The parameter estimates with superscripts are significant $\left({ }^{\mathrm{d}}=p<0.05 ;^{\mathrm{c}}=p<0.01{ }^{\mathrm{a}}=p<0.0001\right)$, as determined by a $t$-test for fixed effects and a Z-test for random effects. AIC $=$ Akaike information criterion, BIC $=$ Bayesian information criterion, $\mathrm{PY}=$ previous year.

Carbon accumulation in P. leiophylla was positively influenced by the increase in the width of the ring and the cambial age $(p<0.0001)$, by the precipitation of the previous year and during the year of formation of the ring ( $p<0.05$ and $p<0.0001$, respectively), as well as by the minimum temperature of the previous year $(p<0.05)$. On the other hand, the annual carbon accumulation decreased with lower 
average and minimum temperatures in the year of formation of the growth ring $(p<0.01$ and $p<0.05$, respectively) (Table 2 ).

\subsection{Climate Sensitivity in Carbon Accumulation}

Significant correlations $(r)$ were found with the four explanatory variables, for the studied species, within the period 1962-2016 in different months ( $p<0.05$, Figure 3).

The accumulation of carbon in P. strobiformis showed positive correlations with the precipitation in the rainy season (June-July of the current year, average $r=0.27, p<0.05$ ) and negative correlations with the precipitation in the winter season of both the previous and current years (specific case December, average $r=-0.29, p<0.05)$.

Carbon accumulation was positively correlated with temperature in certain months, with the highest correlation ( $r$, Pearson) with Tmax in the season from September to December of the previous year and the year of formation of the growth ring. The mean temperature was clearly significant for the accumulation of carbon in this species in the months of October and November, while the minimum temperature showed significance in the period from February to June (excluding April) and also in October of both years.

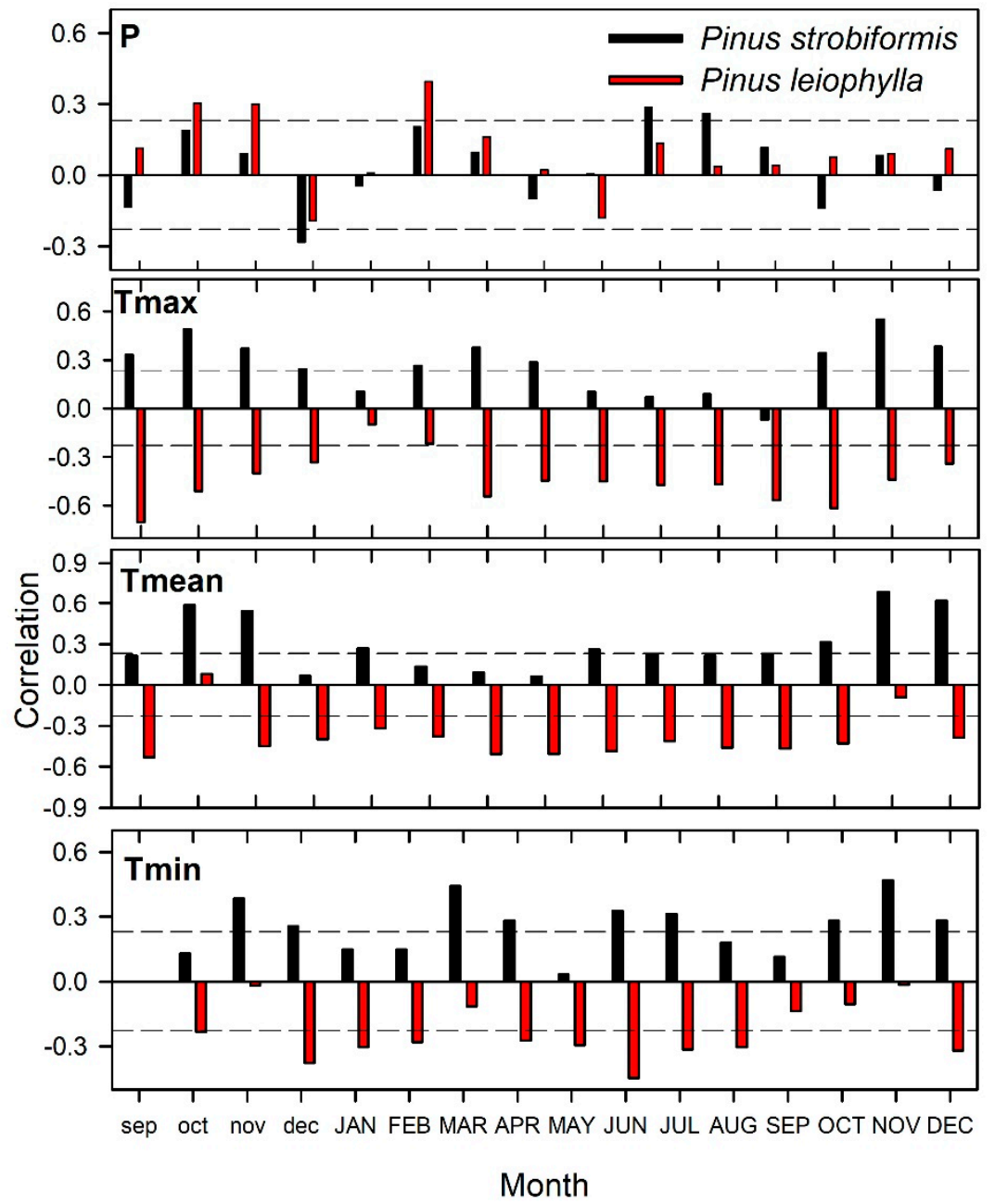

Figure 3. Correlation indexes between carbon accumulation and monthly data of the climatic variables for the two species studied. $\mathrm{P}=$ precipitation, Tmax = maximum temperature, Tmean = average temperature, Tmin = minimum temperature. The months in lowercase and uppercase correspond to the months of the previous year and the current year, respectively. The dashed horizontal lines show the $p=0.05$ level of significance. 
Pinus leiophylla presented a significant positive correlation $(p<0.05)$ of $C$ with respect to precipitation, particularly in October and November of the previous year, as well as February of the ring's formation year, where it obtained the highest value. On the other hand, the carbon accumulation of this species in relation to the different temperatures, showed a negative correlation in several months (Figure 3). Between the maximum temperature and carbon accumulation (C), there was a correlation in the period from September to December of the previous year and from March to November of the year of formation of the growth ring, presenting the highest absolute value of correlation in the month of September of the previous year $(r=-0.69, p<0.05)$. The correlation between the ring width variable and temperature was only significant in the month of September of the previous year and only with respect to the maximum temperature.

In relation with the average temperature, $C$ presents a significant negative correlation in almost all the months year round, with the exception of October (average $r=-0.44, p<0.05$ ). With the minimum temperature, the correlation was negative in the months of November of the previous year until July of the year of the ring's formation, except February and including again November and December of the year of ring's formation (average $r=-0.32, p<0.05$ ).

\subsection{Relationships between Drought and Carbon Accumulation}

The accumulation of carbon had a different response in the two species. Pinus strobiformis expressed a negative correlation with the SPEI drought index (Figure 4). This correlation was higher in absolute terms $(r=-0.3)$ from November to December, considering scales of 1-4 months. In contrast, in P. leiophylla, the accumulation of carbon in relation to drought (SPEI) showed the highest positive response $(r=0.3)$ on the scale of 12 to 20 months from July to October.

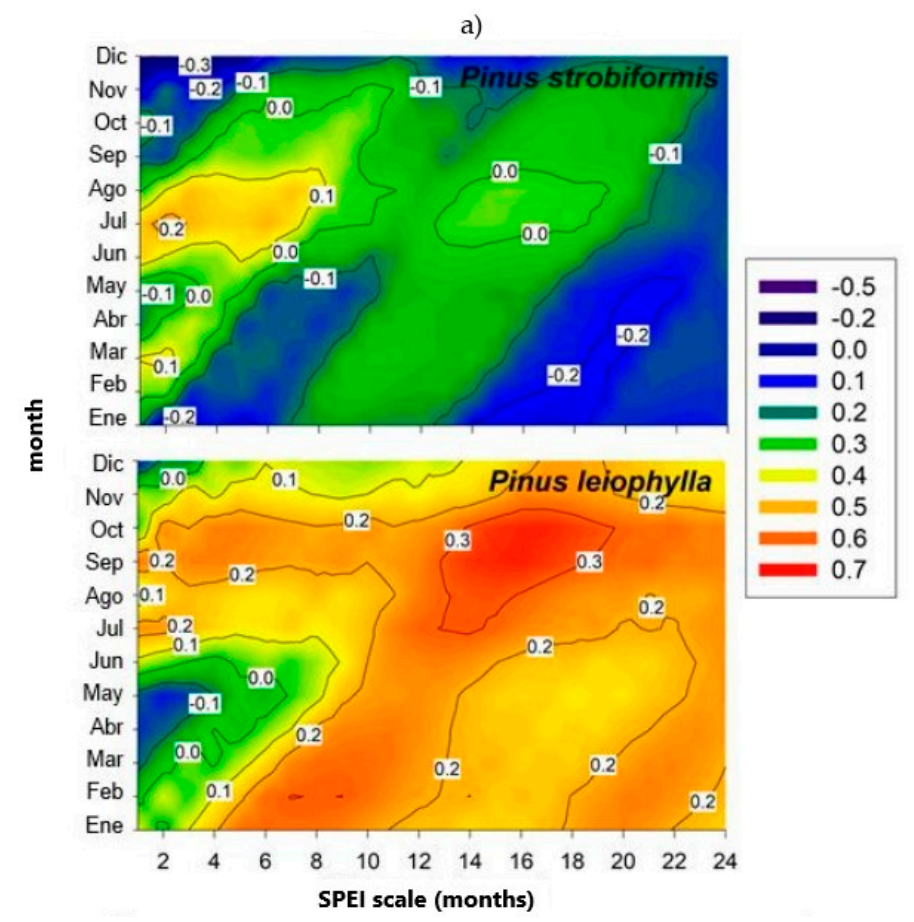

Figure 4. Cont. 
b)

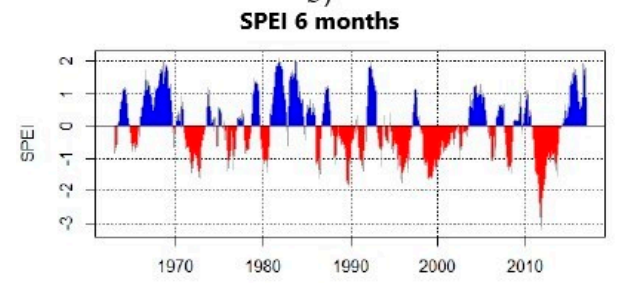

c)

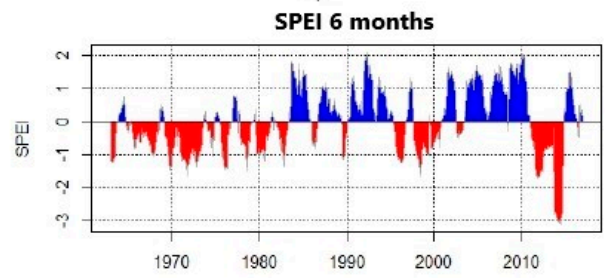

Figure 4. Associations of carbon accumulation by drought for: (a) Pinus strobiformis and Pinus leiophylla. The graphs show the correlation values ( $r$, Pearson) between carbon accumulation and the standardized precipitation and evapotranspiration index (SPEI) drought index on scales from 1 to 24 months (x-axes), calculated from January to December (y-axes); correlations greater than $r=0.35$ are significant $(p<0.01)$. (b,c) show the SPEI drought index (period 1962-2016) for the El Salto and Otinapa stations, respectively; the blue and red bars indicate positive and negative SPEI values corresponding to wet and dry conditions, respectively.

\section{Discussion}

The results showed a differential sensitivity between the analyzed species to climate variability, with the response in terms of carbon accumulation.

Biomass is an important biophysical parameter, helpful to understand the dynamics of carbon. Its space-temporal estimation provides valuable information to calculate the carbon captured and contributes to the scientific management of forests; the varied natural environments and also human activities cause changes in biomass $[47,48]$. Previous studies have shown that the estimation of carbon using allometric equations and considering estimated percentages of carbon concentration in woody biomass, give elements of confidence in the estimation of captured carbon $[18,19,25]$.

The statistical differences detected between the two studied species in terms of carbon accumulation, show the influence of the environmental or climatic differences of each site on the respective wood formation and carbon accumulation $[24,30]$.

Regarding the relationships of the carbon captured with respect to the climatic variables analyzed, it was observed that there were significant correlations in both species. Pinus strobiformis was correlated with precipitation to a lesser extent than P. leiophylla (Figure 3). This could be due to the less limiting humidity conditions in which the first species develops [31]. In the case of P. leiophylla, precipitation had a greater influence on the winter season, which is consistent with what was found in other studies $[49,50]$, in which it was observed that low-intensity precipitation achieves greater infiltration in deep soils, improving their water storage, thus becoming a trigger for the growth and improvement of tree conditions [50-52].

The trend of the positive correlations of carbon captured in P. strobiformis with the different temperature modalities here analyzed, agrees with that reported by Juday et al. [53] who mentioned that warmer conditions favor the growth of trees in cold regions. On the other hand, P. strobiformis could present adaptations to temperature changes, including as a response its capability to develop under the protection of other dominant trees, which prevent the solar rays from reaching it directly $[23,54]$. This emphasizes the ecological importance of P. strobiformis within the succession of forests, given its tolerance to shade [55]. In this sense, it is known that pine species with a wide spatial distribution such as P. strobiformis and P. strobus var. chiapensis can better withstand some effects of climatic changes [56].

The case is the opposite for P. leiophylla, in which negative correlations of carbon captured with temperatures are associated with high evapotranspiration rates, which caused a decrease in carbon uptake since warm conditions affect the cell wall of the tracheids, thus reducing the absorption of carbon by the stomatal closure [57], finding a high vulnerability in the trees of warmer areas to heat stress [58]. 
In the first 15 years of the period analyzed, a greater accumulation of carbon can be observed in P. leiophylla than in P. strobiformis (Figure 2), which decreased notably in the mid-1990s. Our results show that $P$. leiophylla has a high climatic sensitivity $(E P S=0.92)$. The limitation of water combined with high temperatures (Figure 4c) exerts pressure on radial growth, leading to negative impacts on forest productivity and carbon sequestration [51,59-61], which is common in areas with limited water supply [49]. Thus, carbohydrate production is limited given the high evapotranspiration demand.

The opposite occurs in complacent species such as $P$. strobiformis, which commonly lives in humid sites [30,33]. The soil moisture favors metabolic processes in trees, not affecting their growth even when temporary dry conditions are present [50]. The role of latewood as a proxy of larger carbon accumulation is a very interesting question, however, further research on this topic is recommended.

The results of the mixed model (Table 2) partially agree with those reported by Pompa-García and Venegas-González [62]. The variables cambial age and ring width were highly significant within the results obtained in the studies of both species, indicating a strong relationship of ontogenetic influences (age and radial growth) on carbon accumulation in P. strobiformis, while these influences, combined with external (climatic) variables, affected carbon accumulation also in P. leiophylla.

The correlation of the captured carbon with the SPEI drought index was different between the species studied, being positive with P. leiophylla and negative with P. strobiformis (Figure 4). This could be explained because $P$. leiophylla, which develops in dry environments, has limited water resources that exert more pressure on radial growth, reducing the width of the ring and increasing the density of the wood. This increase was also observed in P. pinaster [57], revealing that the investment of carbohydrates in the construction of the cell wall continues despite the scarcity of water, while there was a decrease in the rate of radial growth [23]. This is consistent with the changes in density produced by droughts [63]. In a study carried out in P. strobiformis, it was found that populations acclimatized to the low-water treatment presented lower net $\mathrm{CO}_{2}$ uptake [64], which is consistent with the negative relationship found between drought and accumulation of carbon in the species of the present study (Figure 4). These variations would also imply differences in carbon accumulation and storage and biomass production, implying modifications of forest productivity.

\section{Conclusions}

In this study, growth rings have proven their reliability as proxies of carbon dynamics and their responses to site-specific hydroclimatic variations. The studied species showed significant differences in carbon accumulation. Pinus strobiformis at the mesic site tended to be positively correlated with changes in temperature and precipitation, while at the arid site Pinus leiophylla was negatively correlated with these variables. Something similar occurs in relation to drought, finding that carbon accumulation in the species of the dry site is positively correlated, in contrast to the behavior of the species that grows in the wet site. The sensitivity of carbon sequestration to the climate in both species is relevant in regions where there are abrupt changes in climatic events, such as severe and recurrent droughts that have been scientifically documented in the study area. Our approach found species-specific responses to climatic drivers and that tree ring data can contribute to the evaluation of dynamic carbon balance models.

Author Contributions: Conceptualization, M.P.-G.; methodology, A.C.A.-H. and J.R.P.-M.; formal analysis, A.C.A.-H. and J.R.P.-M.; writing-original draft preparation, A.C.A.-H.; writing-review and editing, A.C.A.-H., J.R.P.-M., J.A.P.-R., J.C.H.-D., J.R.G.-T., J.A.N.-L., M.P.-G.; project administration, M.P.-G.; funding acquisition, A.C.A.-H. and M.P.-G. All authors have read and agreed to the published version of the manuscript.

Funding: This research was funded by CONACYT, grant number CB-2013/222522 and A1-S-21471.

Acknowledgments: The first author expresses thanks to CONACYT for her doctoral-awarded scholarship. We are thankful to the community of "Ejido el Brillante" and to the Technical Manager of that area (Javier Bretado) for the support provided for data collection. We also appreciate the support received from Drs. Martha and Ma. Socorro González Elizondo, as well as the Flor Isela Retana Rentería and Lizeth Ruacho González, from the Herbarium of the Interdisciplinary Research Center for Integral Regional Development, Durango Unit (CIIDIR-Durango), in the determination and measurement of the samples. We thank the Dirección General de Vida Silvestre, 
SEMARNAT (Secretaría de Medio Ambiente y Recursos Naturales, Mexico), for facilitating field sampling. This work was supported by Consejo Nacional de Ciencia y Tecnología (CONACYT-No. A1-S-21471) and DendroRed (https://dendrored.ujed.mx).

Conflicts of Interest: The authors declare no conflict of interest.

\section{References}

1. OCDE. Informe de la Cooperación para el Desarrollo 2014: Movilizar Recursos para un Desarrollo Sostenible, Ediciones OCDE; OCDE: Paris, France, 2014.

2. González-Elizondo, M.S.; González-Elizondo, M.; López-Enríquez, I.L.; Tena-Flores, J.A.; Márquez-Linares, M.A. Cambios y tendencias sucesionales en ecosistemas de Durango. Vidsupra 2005, 1, 5-11.

3. Woodall, C.W.; Westfall, J.A.; D'Amato, A.W.; Foster, J.R.; Walters, B.F. Decadal changes in tree range stability across forests of the eastern U.S. For. Ecol. Manag. 2018, 429, 503-510. [CrossRef]

4. Williams, A.P.; Allen, C.D.; Macalady, A.K.; Griffin, D.; Woodhouse, C.A.; Meko, D.M.; Swetnam, T.W.; Rauscher, S.A.; Seager, R.; Grissino-Mayer, H.D.; et al. Temperature as a potent driver of regional forest drought stress and tree mortality. Nat. Clim. Chang. 2012, 3, 292-297. [CrossRef]

5. Freeman, A.M. The measurement of environmental and resource values. In Theory and Methods; Resources for the Future Press: Washington, DC, USA, 2003.

6. Hassan, R.; Scholes, N.; Ash, N. (Eds.) Ecosystems and Human Well-Being: Current State and Trends; Island Press: Washington, DC, USA, 2005; Volume 1.

7. Brockerhoff, E.G.; Barbaro, L.; Castagneyrol, B.; Forrester, D.I.; Gardiner, B.; González-Olabarria, J.R.; Lyver, P.; Meurisse, N.; Oxbrough, A.; Taki, H.; et al. Forest biodiversity, ecosystem functioning and the provision of ecosystem services. Biodivers. Conserv. 2017, 26, 3005-3035. [CrossRef]

8. Bonan, G.B. Forests and climate change: Forcings, feedbacks, and the climate benefits of forests. Science 2008, 320, 1444-1449. [CrossRef] [PubMed]

9. Brienen, R.J.W.; Phillips, L.; Feldpausch, R.; Gloor, E.; Baker, R.; Lloyd, J.; Lopez-Gonzalez, G.; Monteagudo-Mendoza, A.; Malhi, Y.; Lewis, S.L.; et al. Long-term decline of the Amazon carbon sink. Nature 2015, 519, 344-348. [CrossRef] [PubMed]

10. Sabine, C.L.; Feely, R.A.; Gruber, N.; Key, R.M.; Lee, K.; Bullister, J.L.; Wanninkhof, R.; Wong, C.S.; Wallace, D.W.R.; Tilbrook, B.; et al. The oceanic sink for anthropogenic $\mathrm{CO}_{2}$. Science 2004, 305, 367-371. [CrossRef]

11. Solomon, S. Climate Change 2007-The Physical Science Basis: Working Group I Contribution to the Fourth Assessment Report of the IPCC; Cambridge University Press: Cambridge, UK, 2007.

12. Shimamoto, C.Y.; Botosso, P.C.; Marques, M. How much carbon is sequestered during the restoration of tropical forests? Estimates from tree species in the Brazilian Atlantic forest. For. Ecol. Manag. 2014, 329, 1-9. [CrossRef]

13. Gernandt, D.S.; Pérez-de la Rosa, J.A. Biodiversidad de Pinophyta (coníferas) en México. Rev. Mex. Biodivers. 2014, 85, 126-133. [CrossRef]

14. Cartus, O.; Kellndorfer, J.; Walker, W.; Franco, C.; Bishop, J.; Santos, L.; Fuentes, J.M. A national, detailed map of forest aboveground carbon stocks in Mexico. Remote Sens. 2014, 6, 5559-5588. [CrossRef]

15. González-Elizondo, M.S.; González-Elizondo, M.; Tena-Flores, J.A.; Ruacho-González, L.; López-Enríquez, I.L. Vegetación de la Sierra Madre Occidental, México: Una síntesis. Acta Bot. Mex. 2012, 100, 351-403. [CrossRef]

16. Douterlungne, D.; Herrera-Gorocica, A.M.; Ferguson, B.G.; Siddique, I.; Soto-Pinto, L. Ecuaciones alométricas para estimar biomasa y carbono de cuatro especies leñosas neotropicales con potencial para la restauración. Agrociencia 2013, 47, 385-397.

17. Gómez-Díaz, J.D.; Etchevers-Barra, J.D.; Monterrosos-Rivas, A.I.; Campo-Alvez, J.; Tinoco-Rueda, J.A. Ecuaciones alométricas para estimar biomasa y carbono en Quercus magnoliaefolia. Rev. Chapingo Ser. Cienc. For. Ambiente 2011, 17, 261-272. [CrossRef]

18. Navar, J. Allometric equations for tree species and carbon stocks for forests of northwestern Mexico. For. Ecol. Manag. 2009, 257, 427-434. [CrossRef]

19. Pompa-García, M.; Sigala-Rodríguez, J.A.; Jurado, E.; Flores, J. Tissue carbón concentration of 175 Mexican forest species. iForest 2017, 10, 754-758. [CrossRef] 
20. Sánchez-González, A. Una visión actual de la diversidad y distribución de los pinos de México. Madera Bosques 2008, 14, 107-120. [CrossRef]

21. Van der Putten, W.H. Climate change, aboveground-belowground interactions, and species range shifts. Annu. Rev. Ecol. Evol. Syst. 2012, 43, 365-383. [CrossRef]

22. Suarez, L.M.; Kitzberger, T. Differential effects of climate variability on forest dynamics along a precipitation gradient in northern Patagonia. J. Ecol. 2010, 98, 1023-1034. [CrossRef]

23. Babst, F.; Alexander, M.R.; Szejner, P.; Bouriaud, O.; Klesse, S.; Roden, J.; Ciais, P.; Poulter, B.; Frank, D.; Moore, D.J.P.; et al. A tree-ring perspective on the terrestrial carbon cycle. Oecologia 2014, 176, 307-322. [CrossRef]

24. Babst, F.; Bouriaud, O.; Papale, D.; Gielen, B.; Janssens, A.; Nikinmaa, E.; Ibrom, A.; Wu, J.; Bernhofer, C.; Kostner, B.; et al. Aboveground woody carbon sequestration measured from tree rings is coherent with net ecosystem productivity at five eddy covariance sites. New Phytol. 2014, 201, 1289-1303. [CrossRef]

25. Pompa-García, M.; Sigala, R.J.A. Variation of carbon uptake from forest species in Mexico: A review. Madera Bosques 2017, 23, 225-235. [CrossRef]

26. Acosta-Hernández, A.C.; Pompa-García, M.; Camarero, J.J. An updated review of dendrochronological investigations in Mexico, a megadiverse Country with a high potential for tree-ring sciences. Forests 2017, 8, 160. [CrossRef]

27. Pompa-García, M.; Venegas-González, A.; Júnior, A.A.; Sigala-Rodríguez, J.A. Dendroecological approach to assessing carbon accumulation dynamics in two Pinus species from northern Mexico. Tree Ring Res. 2018, 74, 196-209. [CrossRef]

28. Descroix, L.; Barrios, J.L.G.; Ávalos, J.E. La Sierra Madre Occidental: Una Fuente de Agua Amenazada; Instituto Nacional de Investigaciones Forestales, Agrícolas y Pecuarias: Gómez Palacio, México, 2004.

29. Rzedowski, J. Vegetación de México; Limusa: Ciudad de México, Mexico, 1978.

30. García-Arévalo, A. Vegetación y flora de un bosque relictual de Picea chihuahuana Martínez del norte de México. Polibotánica 2008, 25, 45-68.

31. González-Cásares, M.; Pompa-García, M.; Camarero, J.J. Differences in climate-growth relationship indicate diverse drought tolerances among five pine species coexisting in Northwestern Mexico. Trees 2016, 31, 531-544. [CrossRef]

32. Yocom, L.L.; Fulé, P.Z.; Falk, D.A.; García-Domínguez, C.; Cornejo-Oviedo, E.; Brown, P.M.; Villanueva-Díaz, J.; Cerano, J.; Cortés, C. Fine-scale factors influence fire regimes in mixed-conifer forests on three high mountains in Mexico. Int. J. Wildland Fire 2014, 23, 959-968. [CrossRef]

33. Farjon, A.; Styles, B.T. Flora Neotropica. Pinus (Pinaceae); New York Botanical Garden: New York, NY, USA, 1997.

34. Richardson, D.M.; Rundel, P.W. Ecology and biogeography of Pinus: An introduction. In Ecology and Biogeography of Pinus; Cambridge University Press: Cambridge, UK, 1998; pp. 3-46.

35. García, A.A.; González, E.M.S. Pináceas de Durango; Comisión Nacional Forestal, Instituto de Ecología A.C.: Zapopan, Mexico, 2003.

36. Nehrbass-Ahles, C.; Babst, F.; Klesse, S.; Nötzli, M.; Bouriaud, O.; Neukom, R.; Dobbertin, M.; Franket, D. The influence of sampling design on tree-ring-based quantification of forest growth. Glob. Chang. Biol. 2014, 20, 2867-2885. [CrossRef] [PubMed]

37. Stokes, M.A.; Smiley, T.L. Tree-Ring Dating; The University of Chicago Press: Chicago, IL, USA, 1968.

38. Holmes, R.L. Computer-assisted quality control in treering dating and measurement. Tree Ring Bull. 1983, 43, 69-78.

39. Peters, R.L.; Klesse, S.; Fonti, P.; Frank, D.C. Contribution of climate vs. larch budmoth outbreaks in regulating biomass accumulation in high-elevation forests. For. Ecol. Manag. 2017, 401, 147-158. [CrossRef]

40. Pinheiro, J.C.; Bates, D.M. Linear mixed-effects models: Basic concepts and examples. In Mixed-Effects Models in S and S-Plus; Springer: Berlin/Heidelberg, Germany, 2000; pp. 3-56.

41. R Development Core Team. R: A Language and Environment for Statistical Computing; Version 3.0.1; R Foundation for Statistical Computing: Vienna, Austria, 2017; Available online: http://www.R-project.org (accessed on 3 November 2018).

42. Bunn, A.G. A dendrochronology program library in R (dplR). Dendrochronologia 2008, 26, 115-124. [CrossRef] 
43. Bunn, A.G. Statistical and visual crossdating in R using the dplR library. Dendrochronologia 2010, 28, 251-258. [CrossRef]

44. Bunn, A.; Korpela, M.; Biondi, F.; Campelo, F.; Merian, P.; Qeadan, F. dplR: Dendrochronology Program Library in R. R Package Version 1.6.3. 2015. Available online: https://CRAN.R-project.org/package=dplR (accessed on 21 January 2015).

45. Vicente-Serrano, S.M.; Beguería, S.; López-Moreno, J.I. A multiscalar drought index sensitive to global warming: The Standardized Precipitation Evapotranspiration Index. J. Clim. 2010, 23, 1696-1718. [CrossRef]

46. Beguería, S.; Vicente-Serrano, S.M.; Reig, F.; Latorre, B. Standardized precipitation evapotranspiration index (SPEI) revisited: Parameter fitting, evapotranspiration models, tools, datasets and drought monitoring. Int. J. Climatol. 2014, 34, 3001-3023. [CrossRef]

47. Pan, Y.; Birdsey, R.A.; Fang, J.; Houghton, R.; Kauppi, P.E.; Kurz, W.A.; Phillips, O.L.; Shvidenko, A.; Lewis, S.L.; Canadell, J.G. A large and persistent carbon sink in the world's forests. Science 2011, 333, 988-993. [CrossRef] [PubMed]

48. Shuman, J.K.; Shugart, H.H.; Krankina, O.N. Assessment of carbon stores in tree biomass for two management scenarios in Russia. Environ. Res. Lett. 2013, 8, 045019. [CrossRef]

49. Chang, K.; Price, D.T.; Chena, J.M.; Kurzc, W.A.; Boisvenuec, C.; Hogg, E.H.; Black, T.A.; Gonsamoa, A.; Wua, C.; Hember, R.A. Simulating impacts of water stress on woody biomass in the southern boreal region of western Canada using a dynamic vegetation model. Agric. For. Meteorol. 2014, 198, 142-154. [CrossRef]

50. Pompa-García, M.; González-Cásares, M.; Acosta-Hernández, A.C.; Camarero, J.J.; Rodríguez-Catón, M. Drought influence over radial growth of mexican conifers inhabiting mesic and xeric sites. Forests 2017, 8, 175. [CrossRef]

51. Rodríguez-Catón, M.; Villalba, R.; Morales, M.; Srur, A. Influence of droughts on Nothofagus pumilio forest decline across northern Patagonia, Argentina. Ecosphere 2016, 7, e01390. [CrossRef]

52. Allen, C.D.; Breshears, D.D.; McDowell, N.G. On underestimation of global vulnerability to tree mortality and forest die-off from hotter drought in the Anthropocene. Ecosphere 2015, 6, 1-55. [CrossRef]

53. Juday, G.P.; Alix, C.; Grant, T.A. Spatial coherence and change of opposite white spruce temperature sensitivities on floodplains in Alaska confirms early-stage boreal biome shift. For. Ecol. Manag. 2015, 350, 46-61. [CrossRef]

54. Looney, C.E.; Waring, K.M. Pinus strobiformis (southwestern white pine) stand dynamics, regeneration, and disturbance ecology: A review. For. Ecol. Manag. 2013, 287, 90-102. [CrossRef]

55. Cram, D.; Saud, P.; Baker, T. Structure and Composition of a Dry Mixed-Conifer Forest in Absence of Contemporary Treatments, Southwest, USA. Forests 2017, 8, 349. [CrossRef]

56. Thomas, C.D. Translocation of species, climate change, and the end of trying to recreate past ecological communities. Trends Ecol. Evol. 2011, 26, 216-221. [CrossRef]

57. Campelo, F.; Vieira, J.; Nabais, C. Tree-ring growth and intra-annual density fluctuations of Pinus pinaster responses to climate: Does size matter? Trees 2013, 27, 763-772. [CrossRef]

58. Rehfeldt, G.E.; Jaquish, B.C.; López-Upton, J.; Sáenz-Romero, C.; St Clair, J.B.; Leites, L.P.; Joyce, D.G. Comparative genetic responses to climate for the varieties of Pinus ponderosa and Pseudotsuga menziesii: Realized climate niches. For. Ecol. Manag. 2014, 324, 126-137. [CrossRef]

59. Brzostek, E.R.; Dragoni, D.; Schmid, H.P.; Rahman, A.F.; Sims, D.; Wayson, C.A.; Johnson, D.; Phillips, R.P. Chronic water stress reduces tree growth and the carbon sink of deciduous hardwood forests. Glob. Chang. Biol. 2014, 20, 2531-2539. [CrossRef]

60. McDowell, N.; Pockman, W.T.; Allen, C.D.; Breshears, D.D.; Cobb, N.; Kolb, T.; Plaut, J.; Sperry, J.; West, A.; Williams, D.G.; et al. Mechanisms of plant survival and mortality during drought: Why do some plants survive while others succumb to drought? New Phytol. 2008, 178, 719-739. [CrossRef]

61. McDowell, N.G. Mechanisms linking drought, hydraulics, carbon metabolism, and vegetation mortality. Plant Physiol. 2011, 155, 1051-1059. [CrossRef]

62. Pompa-García, M.; Venegas-González, A. Temporal variation of wood density and carbon in two elevational sites of Pinus cooperi in relation to climate response in northern Mexico. PLoS ONE 2016, 11, e0156782. [CrossRef] [PubMed] 
63. Britez, M.R.D.; Sergent, A.S.; Martinez, A.M.; Bréda, N.; Rozenberg, P. Wood density proxies of adaptive traits linked with resistance to drought in Douglas fir (Pseudotsuga menziesii (Mirb.) Franco). Trees 2014, 28, 1289-1304. [CrossRef]

64. Goodrich, B.A.; Waring, K.M.; Kolb, T.E. Genetic variation in Pinus strobiformis growth and drought tolerance from southwestern US populations. Tree Physiol. 2016, 36, 1219-1235. [CrossRef] [PubMed]

Publisher's Note: MDPI stays neutral with regard to jurisdictional claims in published maps and institutional affiliations.

(C) 2020 by the authors. Licensee MDPI, Basel, Switzerland. This article is an open access article distributed under the terms and conditions of the Creative Commons Attribution (CC BY) license (http://creativecommons.org/licenses/by/4.0/). 